Article

\title{
Dominican Chant and Dominican Identity
}

\section{Innocent Smith}

Dominican House of Studies, 487 Michigan Ave NE, Washington, DC 20017, USA;

E-Mail: innocent.smith@opeast.org

Received: 25 August 2014; in revised form: 12 September 2014 / Accepted: 16 September 2014 / Published: 29 September 2014

\begin{abstract}
The Order of Preachers possesses a venerable chant tradition that dates back to the thirteenth century. This essay describes Dominican chant, showing how it developed as a consequence of the attitudes to the liturgy expressed in the Ancient Constitutions of the Order of Preachers. These constitutions stressed that the liturgy was to be performed with careful attention to bodily posture, with a succinctness and brevity that would allow time for study and preaching, and with gradations of solemnity that would express the inner hierarchy of parts of the liturgy and of the liturgical year. After the initial development of the repertoire, Dominican chant has gone through periods of decline and revival, which are briefly traced in this article together with a consideration of the place of the chant in the contemporary practice of the Order. Throughout the last eight centuries, the chant of the Order of Preachers has played an important role in the inculcation and preservation of Dominican identity within the Order and in the lives of individual friars and sisters.
\end{abstract}

Keywords: Dominican chant; Gregorian chant; Humbert of Romans; Thomas Aquinas; progressive solemnity; liturgy

\section{Introduction}

Dominican chant is a dialect of the Latin liturgical chant repertoire popularly known as Gregorian chant. ${ }^{1}$ When St. Dominic (1170-1221), a canon regular from Osma in Spain, founded the Order of Preachers in 1216, he established a mode of life that balanced liturgical prayer, monastic observance, and academic study as a preparation for and mode of sustaining the apostolic ministry of preaching.

For a broad overview of Latin liturgical chant, see [1], especially the consideration of various repertoires and reforms of Latin chant in pp. 524-621. 
Unlike many earlier forms of monastic life that emphasized stability of place, St. Dominic envisaged a form of life in which friars could easily travel from priory to priory and from church to church in order to carry out their preaching activity more effectively. In addition, St. Dominic instituted a mode of governance (perhaps modeled in certain respects on the Order of Cîteaux founded in the previous century) in which friars from local communities would participate in a representative form of centralized governance by means of Provincial and General Chapters and by means of visitations in which superiors of the Order could inspect the mode of life of local communities in order to ensure a flourishing of communal and apostolic life. Over the course of the 13th century, the mobility of the friars led to the recognition of a need for a standardized form of the liturgy that could be used by friars in different communities in the midst of the tremendous liturgical diversity then present in the Catholic world. In the early 13th century, the followers of St. Dominic gradually began to compile a repertoire of liturgical chants that was subsequently standardized in the mid-13th century and which has continued to develop and expand over the eight centuries of the Order's existence. These Dominican chants often share their texts with the broader Roman rite but often feature melodic variations from the broader repertoire. Today, these variant melodies may still be sung in celebrations of the Mass and Liturgy of the Hours in the contemporary Ordinary Form of the Roman Rite. In this essay, brief and succinct consideration will be given to the distinctive aspects and history of the Dominican chant repertoire.

\section{Dominican Chant and the Body}

For the early Dominicans, chant was an integral aspect of divine worship. According to Humbert of Romans, a thirteenth century Dominican who exercised a profound influence on the development of the Dominican liturgical tradition, divine worship requires a profound unity of heart, mouth, and body ([2], p. 160). ${ }^{2}$ Thus, a complete consideration of Dominican chant must consider not only the words or the melodies that are sung by the mouth, but also the preparation of the heart and the posture of the body.

Despite the association of Gregorian chant with monks floating in the air singing ethereal melodies conjured up for many today due to the success of the 1994 Chant album of the Benedictine Monks of Santo Domingo de Silos, chant for Dominicans has always been understood as being fundamentally embodied. It is striking that the first chapter of the Dominican Constitutiones antiquae, adapted from the Constitutions of Premontré and compiled over the period from 1217-1235, already specifies certain bodily postures for the singing of various types of chant: for instance, a profound bow is made while singing the Gloria Patri and when listening to the priest sing the collect at the Mass and Office, as well as during the final verses of the hymns of the office, the Suscipe deprecationem nostram of the Gloria, the Homo factus est of the Creed, and so forth; the brothers genuflect while singing the

2 Humbert of Romans (c. 1200-1277) administered a standardization of the Dominican liturgy while serving as the fifth Magister ordinis [Master of the Order] from 1254-1263. After his resignation as Master, Humbert continued to have a profound influence on the development of various aspects of the Dominican life through his commentaries on the Constitutions of the Order of Preachers and the Rule of St. Augustine and his writings on the duties of various friars in the Order. On Humbert's life and significance, see [3]. A more recent, though as yet unpublished, critical edition of Humbert's Expositio may be found in [4]. 
opening sections of the Salve sancta parens (Officium/Introit antiphon) and Veni sancte Spiritus (sequence); further, one side of the choir stands during the first psalm while the other sits, and then sits while the second side stands, in alternation ([5], pp. 313-14). These regulations indicate that from the earliest days of the Order there was a well-established liturgical custom in which chant was integrated into a system of postures that were carefully collated with the liturgical action at hand. ${ }^{3}$ In his Commentary on the Constitutions, Humbert of Romans offers extensive explanations of the significance of the posture of the body during the different chants ([2], pp. 160-71). Throughout its history, the Order has retained this fundamental link of chant and bodily posture. ${ }^{4}$

For the medieval Dominicans, chant was understood to play an important role in the cultivation of personal devotion on the part of those participating in communal worship. According to the Dominican friar St. Thomas Aquinas (c. 1224-1274), the use of the body and the voice in divine worship helps arouse devotion in the heart [mens or affectus] of the worshipper, ${ }^{5}$ and allows one to serve God "with everything that he has from God, that is, not only with the mind [mente], but also with the body [corpore]". ${ }^{6}$ For Thomas, "it was fittingly instituted that chant should be used in the divine praises, that the souls of the weak might be more incited to devotion,", although he makes an important distinction for Dominicans by nothing that "it is a more noble mode to lead men to devotion by teaching and preaching than through chant." 8

Another aspect of the relationship of chant and the body is the Dominican emphasis on strong or virile singing ([2], p. 105). St. Dominic was known for his strong and clear voice; in choir, he would walk from one side to the other, exhorting the brothers to sing with a strong voice, and while on journeys would frequently sing liturgical hymns such as the Ave Maris Stella and Veni Creator Spiritus ([12], p. 140). Paradoxically, St. Dominic's strong singing would also lead him to tears: he was also known to prefer to celebrate the Sung High Mass when he could find a suitable church, and when he would celebrate Mass, tears would often run down his face ([12], pp. 124, 162). We may also recall that St. Thomas Aquinas was given the gift of tears while praying the liturgy, particularly during the chanting of the Media vita (Nunc dimitis antiphon) [13].

3 In the late 13th century, a text known as the "Nine Ways of Prayer of St. Dominic" associated various liturgical postures with the private prayer of St. Dominic, offering an example for Dominicans who wished to imitate these prayer postures of their founder; see [6]. For further considerations on the body and gesture in the Middle Ages, see [7].

4 For a contemporary application of these principles, see the guidelines concerning posture at Mass and Office indicated in [8], pp. lxxix-lxxxiv.

5 Thomas Aquinas, ST II-II, q. 81, a. 7, response: "Et ideo in divino cultu necesse est aliquibus corporalibus uti, ut eis, quasi signis quibusdam, mens hominis excitetur ad spirituales actus, quibus Deo coniungitur”; cf. ST II-II, q. 91, a. 1, response: "Proficit etiam laus oris ad hoc quod aliorum affectus provocetur in Deum."

6 Thomas Aquinas, ST II-II, q. 83, a. 12, response: “[S]ecundum totum illud quod ex Deo habet, idest non solum mente, sed etiam corpore."

7 Thomas Aquinas, ST II-II, q. 91, a. 2, response: “[S]alubriter fuit institutum ut in divinas laudes cantus assumerentur, ut animi infirmorum magis provocarentur ad devotionem."

8 Thomas Aquinas, ST II-II, q. 91, a. 2, ad 3: “[N]obilior modus est provocandi homines ad devotionem per doctrinam et praedicationem quam per cantum.” For further reflections on the relationship between liturgical solemnity and devotion in Thomas Aquinas, see [9]. For a detailed treatment on Aquinas's appreciation of various aspects of the medieval liturgy and his place within the medieval liturgical commentatorial tradition, see [10,11]. 


\section{The Constitutiones Antiquae and Dominican Chant}

The fourth chapter of the first distinction of the Constitutiones antiquae contains succinct articulations of four other aspects of the Dominican attitude to chant:

"Our brothers ought to hear Matins and Mass and all the canonical hours together, and they ought to eat together, unless otherwise the prelate wishes to dispense anyone. All the hours in the church should be said briefly and succinctly, lest the brothers should lose devotion or be at all impeded in their study. We say that this is to be done such that in the middle of the verse a metrum with a pause should be preserved, not by extending the voice at the pause or at the end of the verse, but, as was said, they should be ended briefly and succinctly. However, this should be observed to a greater or lesser extent according to the season." ([5], p. 316). ${ }^{9}$

\subsection{Communal Dimensions of Dominican Chant}

First, the constitutions make it clear that the celebration of the liturgy is a communal task. This has dramatic repercussions for the context and the way in which the chants are sung. Most notably, the repertoire is divided amongst a wide range of brothers, which required that no one be lazy in choir ([2], p. 159).

The most important role was that of the cantor, who according to Humbert, was to be diligent and solicitous in all things that pertained to the office, correcting the brothers in a manly way when necessary and making hand gestures when the rhythm of the chant was notably confused ([2], p. 159; [14], p. 244). Humbert remarks that the cantor was to be obeyed by all the brothers, but somewhat wryly remarks that this applied only to those things which pertain to his office! ([2], p. 159). The cantor was also to correct visiting clerics who did not observe the pauses or melodies correctly ([14], p. 242). The cantor was assisted by the succentor in various tasks, but who had the right to correct the cantor in chapter, if not in choir ([14], pp. 245-46). In addition to instructing and correcting the brothers regarding the chant, the cantor had the duty of preparing the tabula, a list of assignments for the performance of different elements of the liturgy that was sung on Saturdays to alert the brothers to their upcoming duties for the week ([14], pp. 240-41). From the exemplar tabula provided in the medieval Dominican Martyrology, we can get a sense of the division of the parts of the liturgy within the community: different brothers may be assigned for each of the readings and responsories, for the invitatory, for the responsories of the hours other than matins, and so forth [15]. ${ }^{10}$

Despite the emphasis on the communal participation in the liturgy, the first sentence of chapter four of the Constitutiones antiquae makes it clear that that an individual may sometimes be legitimately absent from the choral office. Humbert points out that those who have certain official duties may

9 "Matutinas et missam et omnes horas canonicas simul audiant fratres nostri et simul comedant, nisi cum aliquibus prelatus aliter dispensare voluerit. Hore omnes in ecclesia breviter et succincte taliter dicantur, ne fratres devotionem amittant et eorum studium minime impediatur. Quod ita dicimus esse faciendum, ut in medio versus metrum cum pausa servetur, non protrahendo vocem in pausa vel in fine versus, sed, sicut dictum est, breviter et succincte terminetur. Hoc tamen magis et minus pro tempore observetur."

10 Cf. Rome, Santa Sabina XIV L1, f. 14; London, British Library ms. add. 23935, fols. 48v-49r. The Martyrology provided for the daily chapter meetings in which brief accounts of the saints were read and at which some communal business was conducted. 
sometimes be absent, as well as lay brothers who may instead hear the Mass "sine nota" ([2], p. 78). In another context, Humbert points out that on certain occasions the office may be performed "sine nota", i.e., without singing, pointing out that "chant is not of the substance of the canonical hours to which we are bound" ([2], p. 82). ${ }^{11}$ Humbert acknowledged that smaller communities might legitimately celebrate the office without singing the full melodies ( $c f .[2]$, p. 102). These sources indicate that chant was understood by the early Dominicans to be a normative aspect of Dominican life, but not absolutely binding in every circumstance.

\section{2. "Breviter et Succincte"}

The Constitutiones antiquae ordered that the liturgy be sung "briefly and succinctly" (breviter et succincte) so that the devotion of the brothers should not become lax, and that their study might be minimally impeded. According to Humbert of Romans, study was not to be preferred to prayer as such, but to overly prolix prayer ([2], p. 97). Thomas Aquinas writes within this tradition when he states that liturgical prayer should not last such a long time that the devotion of the participants would grow slack in their devotion. ${ }^{12}$ Humbert offers several reasons why a shorter office is better than a longer one, the first of which is that otherwise the choir would be evacuated as many would seek occasions of staying away based on this prolixity! ([2], pp. 85-86).

This emphasis on brevity led to one of the most distinctive characteristics of Dominican chant: the Dominican versions of chants often have one or two notes in places where other traditions have three or more, and omit certain melodic repetitions that appear in other chant traditions ([16], pp. 199-207). A comparison of the chant manuscripts from before and after the revision of Humbert of Romans shows that these abbreviations were a self-conscious development on the part of the early friars ([16], pp. 327-29). In some cases, however, Dominican versions of chants can be more ornate than versions sung in other chant traditions, for instance in the case of the Dominican setting of the Passion sung on Palm Sunday and Good Friday or the Exultet of Holy Saturday. In addition to the length of the melodies, there are clear indications that the early Dominicans self-consciously sang the chants in a way faster than many of their contemporaries. ${ }^{13}$

\subsection{Pauses in Dominican Chant}

Despite the emphasis on singing breviter et succincte, brevity was not meant to lead to sloppiness or irreverence. The constitutions also ordered that pauses were to be made in the middle of verses of the psalms which were nevertheless to be ended briefly and succinctly. According to Humbert, pauses were to be made in the middle of psalms to prevent confusion, although it is clear from his writings that the length and position of the pauses were a matter of some confusion ([2], pp. 98, 102, 159; [14], pp. 242-44). Humbert distinguishes between a pausa brevis and a pausa maior that are made during

11 "Cantus non est de substantia horarum canonicarum ad quas tenemur."

12 Thomas Aquinas, ST II-II, q. 83, a. 14.

13 Humbert of Romans contrasts the Dominican mode of singing to that of "certain religious": "non nimis morose, sicut faciunt quidam religiosi" ([2], p. 97). Although it is not clear exactly which groups of religious are intended by this "quidam," it may perhaps include groups such as the Carthusians who thought the monk's duty was "to lament rather than to sing" (see [17]). 
the recitation of the psalms ([2], p. 101). He points out, however, that these brief and major pauses are not only made in psalms and canticles but also in hymns, in chants such as the Gloria in excelsis, the Credo in Deum, and the Te Deum laudamus - indeed, "in everything that is chanted" ([2], p. 102). Humbert explains that it is expedient to use "virgulas transversales" [vertical bars] to note the location of pauses in books, which he mentions is done already in certain churches ([2], 102-03; [18]).

\subsection{Gradations in Solemnity}

Finally, the constitutions decree that the length of the pauses is observed "magis et minus pro tempore". Humbert explains that on solemn feast days, the office is sung with longer pauses within the psalms; this is possible because on those days the friars are not as occupied with study, and thus have more leisure to sing the office in a more solemn manner ([2], p. 110). In addition, however, the more solemn melodies add to the devotion of the faithful, and point to the great future feast in which our praise will be continuous and most devout ([2], p. 111). The variation of the length of pauses within the psalms referred to here is related to a systematic form of melodic solemnity that may be discerned also in other aspects of the Dominican liturgy. In the melodies assigned for various texts used on several ranks of feasts, such as the Ordinary of the Mass or the hymns of the Common of Saints, a gradated solemnity may be observed that distinguishes a major feast from a lesser one or a ferial day. For instance, the hymn Te lucis is sung on every day outside of Lent to a variety of melodies based on the rank of the feast; on a totum duplex feast, there is a very ornate melody, on a duplex feast there is a slightly simpler melody, and so forth. ${ }^{14}$ The same text is sung on ferial days to a very simple melody. The same phenomenon may be observed in the settings for the Kyrie, Gloria, Sanctus, Agnus Dei, and Ite missa est.

A related aspect of solemnity is articulated by the thirteenth-century Dominican Jerome of Moravia in chapter twenty-four of the Tractatus de Musica: in composing new melodies for feasts, Jerome suggests that the Magnificat antiphons should be composed according to a set of principles that lead to the most beautiful type of chant, whereas the other antiphons may be composed in a less beautiful manner ([20], pp. 161-66). ${ }^{15}$ Thus, within a particular set of chants for a feast there are some that are of greater solemnity than others. This distinction also seems to be implicit in the more solemn melodies assigned for the Mass, where the Gradual, Alleluia, and Offertory melodies are almost always considerably more ornate than those of the introit and communion antiphons. Like many repertoires of Latin chant, the Dominican system of progressive solemnity thus includes both variations based on the rank of a feast, and variations based on the importance of a particular liturgical element.

\section{History of the Dominican Chant Repertoire}

According to Humbert of Romans, in the beginning years of the Order a great diversity of liturgical practice was found in the Order, at some point a single office was compiled for the sake of uniformity

14 In the medieval Dominican liturgy, there were was a range of six ranks for feast days: Totum duplex, Duplex, Semiduplex, Simplex, Trium lectionum, Memoria; for a discussion of the origins and meanings of these terms, see ([19], pp. 78-83).

15 On the background of Jerome, see [21]. For an English translation of the Tractatus, undertaken from the 1935 critical edition by Simon M. Cserba, see [22]. 
in practice for the highly mobile community ([2], p. 152). In the 1240s, four friars from the provinces of France, England, Lombardy, and Germany were commissioned to coordinate the liturgical books used in the various provinces; their work was approved by several chapters, but was not widely accepted within the Order. Several liturgical manuscripts remain which represent the musical practice of the Order before and during the time of the four friars ([16], pp. 37-40). ${ }^{16}$ These early manuscripts are less influenced by the Cistercian chant reform than the manuscripts from the revision of Humbert of Romans ([16], p. 328; [23]).

In 1254, the newly elected Magister ordinis Humbert of Romans was commissioned to prepare a final revision that eventually met with acceptance throughout the Order. The exemplars of Humbert's revision contained fourteen books, including the Antiphonale (chants for the Divine Office), the Graduale (chants for the Mass), and the Processionarium (chants for liturgical processions), which were the principal chant volumes ([19]; [24]; [25], pp. 359-65). In addition to the unified exemplar copies, individual volumes of the repertoire of Humbert are found in a variety of formats; the chants of the Mass, for instance, were copied both in the form of individual Graduals and within notated Missals. When new feasts were added to the Dominican liturgy, for instance Thomas' liturgy for the Feast of Corpus Christi (belatedly adopted by the Order in the early 14th century ([26], pp. 183-85)), they would often inserted within earlier manuscripts. Aside from the offices composed in the 13th century for the first two canonized Dominican saints, Dominic and Peter Martyr, the two most significant liturgical offices of the later Middle Ages were those of Catherine of Siena and Vincent Ferrer [27].

Manuscripts of Dominican chant continued to be widely produced through the 16th century, and were even occasionally made in later centuries. With the advent of the printing press, Dominican liturgical books were printed as early as the end of the 15th century, and by the early 16th century printed chant books, including psalters, graduals, and processionals, began to be widely produced ([28], pp. 181-93; [29]). Chant editions continued to be produced in the 17th century and in the early part of the 18th century a nearly exhaustive set of Dominican chant books were produced at Paris. After the turmoil of the French revolution, a new set of books began to be produced by the French Dominican Pie Bernard, O.P., first on the basis of late medieval sources and towards the end of the 19th century based on a 13th century codex which was taken to be one of the exemplar copies of the revision of Humbert of Romans [30]. Influenced by the chant revival at Solesmes, Bernard devised a new rhythmic notation that was officially used by the Order from 1890 until 1965 [31]. In the 20th century, further volumes were produced based on the 13th century texts. At the impetus of Dominique Delalande, O.P., the Order decided in the 1960s to adopt a modified version of the Solesmes rhythmic markings in place of the notation devised by Bernard, but the widespread adoption of the vernacular in the late 1960s meant that a full set of volumes with the new notation never appeared [32].

Since the adoption of the revised Roman rites by the Order beginning in 1968, chants from the Order's liturgical heritage have continued to be sung to varying extents in Dominican communities in accord with the provisions of the 1982 Proprium Officiorum Ordinis Prcedicatorum and the 1985 Missale et Lectionarium, which assign chants from the Dominican chant tradition for various liturgical

16 The most important chant manuscripts before the reform of Humbert are Rome, Bibl. Vat. lat. 10773 (gradual), Malibu, CA, Getty Museum, Ludwig V 5 (noted missal), and Rome, Santa Sabina XIV L2 (noted breviary). 
feasts of the year and call for the preparation of new editions of the chants of the Order. ${ }^{17}$ In recent years, several audio recordings have been made that represent various approaches to the Dominican chant repertoire. ${ }^{18}$ In the last decade, scans of most of the 19th and 20th-century editions of the Dominican chant have become available on the Internet, and new editions of the Dominican chant repertoire have been prepared for liturgical use in various provinces of the Order according to the Ordinary Form of the Roman Rite.

\section{Conclusions}

The Order of Preacher's attitude to chant was already articulated in the early 13th-century Constitutiones antiquae. The fundamental characteristics of this attitude are recognition of an integral link between chant and the body, an emphasis on communal celebration of the liturgy that allows for the absence of individuals, a practice of performing chants briefly and succinctly, and a sophisticated sensitivity to gradations of solemnity. These attitudes led to the development of a distinct chant repertoire in the mid-13th century as an expression of these fundamental approaches. The Order is the cause, and the chant repertoire is the effect. However, once the repertoire is formed, it in turn helps form a Dominican identity for individuals who enter the Order.

A related phenomenon may be observed in the case of individual Dominicans who are venerated as saints. Their mode of life and their specific path to holiness was partially formed by their liturgical life. Each of the Dominican saints sang the petition that Christ might "deign to place us among your saints and your elect" (nos collocare digneris inter sanctos et electos tuos) in the Lenten antiphon $O$ Rex gloriose, and now they themselves are among the saints that their successors in the Order are referring to when they sing this chant. Similarly, after the canonization of St. Dominic, the Order began to sing the request that Dominic would "join us to the blessed" (nos junge beatis) in the O Lumen. The text and melody of the chants have remained the same, but the referent of "saints" or "blessed" is continually growing as the Order progresses through history, giving those who sing it at a later date a sense of confidence that the life they are living may in fact help them to become saints. Further, just as individual Dominican saints and blesseds have received special charisms or gifts from the Holy Spirit for the sake of undertaking unusual tasks or for offering an extraordinary witness of sanctity, these distinctive elements of their lives are in turn put forward as exemplars for their successors in the Order in the antiphons and other chants of the saint's feast that describe the lives of the saints. Thus, the liturgy helps to form a Dominican saint, and the liturgy composed in honor of that saint helps to form other Dominicans.

In this essay, we have explored the distinctive attitudes to chant expressed by the early Dominicans and considered the development of the chant repertoire as a practical expression of these principles. Throughout the last eight centuries, the chant of the Order of Preachers has played an important role in the inculcation and preservation of Dominican identity within the Order and in the lives of individual

17 See in particular the section "Cantus gregorianus et aliae formae cantus" in the "Adnotationes complementares" of [8], $\S \S 24-27$, pp. 15-16.

18 Cf. Choeur Des Frères Dominicains De La Province De France, dir. André Gouzes, Chant Grégorien-Liturgie Dominicaine (1994). Friars of the Holy Trinity Convent in Cracow, Veni Lumen Cordium (1990); Alma redemptoris (1991); Requiem (1991); In Epiphania Domini (1997); In Nativitate Domini (2000). 
friars and sisters. Further research remains to be undertaken to establish a better sense of the distinctiveness and commonality of the Dominican chant repertoire with respect to other dialects or repertoires of Latin chant, such as those used by the Franciscans, the Cistercians, and the various local churches and cathedrals of the Christian world in the middle ages. Nevertheless, the Dominican chant repertoire is a subject of great importance on account of the influence it has wielded throughout history in the formation of Dominican saints and theologians.

\section{Acknowledgments}

An earlier version of this essay appeared in German as [33]. All translations of Latin texts are my own.

\section{Abbreviation}

ST: Summa Theologiae.

\section{Conflicts of Interest}

The author declares no conflict of interest.

\section{References}

1. David Hiley. Western Plainchant: A Handbook. Oxford: Clarendon Press, 1993.

2. Humbert of Romans. "Expositio in Constitutiones." In Opera de vita regulari. Edited by Joachim Joseph Berthier. Rome: A. Befani, 1889, vol. 2, pp. 1-178.

3. Edward Tracy Brett. Humbert of Romans: His Life and Views of Thirteenth-Century Society (Studies and Texts 67). Toronto: Pontifical Institute of Mediaeval Studies, 1984.

4. Sonja Reisner. "Die Expositio super constitutiones fratrum Ordinis Praedicatorum des Humbertus de Romanis.” Ph.D. Dissertation, Universität Wien, Austria, November 2004.

5. Antoninus Hendrik Thomas, ed. "Constitutiones antiquae O.P." In De Oudste Constituties van de Dominicanen: Voorgeschiedenis, Tekst, Bronnen, Ontstaan en Ontwikkeling (1215-1237). Louvain: Bureel van de R.H.E. Universiteitsbibliotheek, 1965, pp. 304-69.

6. Jean-Claude Schmitt. "Between Text and Image: The Prayer Gestures of Saint Dominic.” History and Anthropology 1 (1984): 127-62.

7. Jean-Claude Schmitt. La Raison des gestes dans l'occident médiéval. Paris: Gallimard, 1990.

8. Order of Preachers. Proprium Officiorum Ordinis Praedicatorum ad normam decretorum sacrosancti œcumenici concilii Vaticani II instauratum reverendissimi patris fratris Vincentii de Couesnongle eiusdem ordinis magistri iussu editum. Editio typica. Rome: S. Sabinae, 1982.

9. Thomas Augustine Becker. "The Role of Solemnitas in the Liturgy According to Saint Thomas Aquinas." In Rediscovering Aquinas and the Sacraments: Studies in Sacramental Theology. Chicago: Hillenbrand Books, 2009, pp. 114-35.

10. Franck Quoëx. "Thomas d'Aquin, mystagogue: L'expositio missae de la Somme de théologie (IIIa, q. 83, a. 4-5).” Revue Thomiste 105 (2005): 179-225. 
11. Franck Quoëx. “Thomas d'Aquin, mystagogue (II): L'expositio missae de la Somme de théologie (IIIa, q. 83, a. 4-5).” Revue Thomiste 105 (2005): 435-72.

12. Marie-Hyacinthe Laurent, ed. "Acta Canonizationis S. Dominici." In Monumenta Historica Sancti Patris Nostri Dominici, Fasc. II. Rome: Institutum Historicum FF. Praedicatorum, ad S. Sabinae, 1935, pp. 89-194.

13. André Duval. "The Tears of Brother Thomas." Translated by Cassian Derbes. Dominicana 54 (2011): 62-69.

14. Humbert of Romans. "Instructiones de officiis ordinis." In Opera de vita regulari. Edited by Joachim Joseph Berthier. Rome: A. Befani, 1889, vol. 2, pp. 179-371.

15. Franciscus-Maria Guerrini, ed. "De modo scribendi et legendi tabulam." In Ordinarium juxta ritum Sacri Ordinis Fratrum Praedicatorum jussu rev.mi patris fr. Ludovici Theissling eiusdem ordinis magistri generalis editum. Rome: Apud Collegium Angelicum, 1921, pp. 221-32.

16. Robert B. Haller. "Early Dominican Mass Chants: A Witness to Thirteenth Century Chant Style." Ph.D. Dissertation, The Catholic University of America, Washington, DC, USA, 1986.

17. Mary Berry. "Carthusian monks." In The New Grove Dictionary of Music and Musicians. Edited by Stanley Sadie. London: Macmillan, 1980, vol. 3, pp. 838-39.

18. Michel Huglo. "Dominican and Franciscan Books: Similarities and Differences between Their Notations." In The Calligraphy of Medieval Music. Edited by John Haines. Turnhout: Brepols, 2011, pp. 195-202.

19. Louis Rousseau. De Ecclesiastico Officio Fratrum Praedicatorum Secundum Ordinationem Venerabilis Magistri Humberti de Romanis. Rome: A. Manuzio, 1927.

20. Jerome of Moravia (Hieronymus de Moravia). Tractatus de Musica. Edited by Christian Meyer, Guy Lobrichon and Carola Hertel-Geay. Turnhout: Brepols, 2012.

21. Michel Huglo. "Hieronymus de Moravia: 'frère morave' ou 'Scottish Blackfriar'?" In Nationes, Gentes und die Musik im Mittelalter. Edited by Frank Hentschel and Marie Winkelmüller. Berlin: De Gruyter, 2014, pp. 423-34.

22. Laura Weber. "Intellectual Currents in Thirteenth Century Paris: A Translation and Commentary on Jerome of Moravia's." Ph.D. Dissertation, Yale University, New Haven, CT, USA, December 2009.

23. Dominique Delalande. Le Graduel des Prêcheurs: Recherches sur les sources et la valeur de son texte musicale. Paris: Cerf, 1949.

24. Eleanor Joyce Giraud. "The Production and Notation of Dominican Manuscripts in Thirteenth-Century Paris." Ph.D. Dissertation, University of Cambridge, Cambridge, UK, September 2013.

25. John Haines. “The Origins of the Musical Staff.” Musical Quarterly 91 (2008): 327-78.

26. James A. Weisheipel. Friar Thomas d'Aquino: His Life, Thought, and Work. Garden City: Doubleday, 1974.

27. Terry David Brown. "Songs for the Saints of the Schism: Liturgies for Vincent Ferrer and Catherine of Siena.” Ph.D. Dissertation, University of Toronto, Toronto, Ontario, Canada, 1995.

28. Robert Stevenson. Music in Aztec and Inca Territory. Berkeley: University of California Press, 1968.

29. Bernardo Fueyo Suárez. "Obras de Fray Juan de Palencia († 1580), cantor del Convento de San Esteban.” Ciencia Tomista 134 (2007): 449-94. 
30. Leonard E. Boyle. "A Material Consideration of Santa Sabina MS. XIV L 1.” In Aux origines de la liturgie dominicaine: Le manuscrit Santa Sabina XIV L1. Edited by Leonard E. Boyle, Pierre-Marie Gy and Pawełs Krupa. Paris: CNRS Editions, 2004, pp. 19-42.

31. Innocent Smith. "Medieval and Modern Dominican Chant in the 19th Century." In Chant: Old and New. Edited by William Renwick. Lions Bay: Institute of Mediaeval Music, 2012, pp. 15-47.

32. Augustine Thompson. "Postconciliar Reform of the Dominican Rite Liturgy: 1962-1969." Antiphon 15 (2011): 299-317.

33. Innocent Smith. "Dominikanischer Choral: Haltung und Heiligkeit." Wort und Antwort 53 (2012): 21-26.

(C) 2014 by the author; licensee MDPI, Basel, Switzerland. This article is an open access article distributed under the terms and conditions of the Creative Commons Attribution license (http://creativecommons.org/licenses/by/4.0/). 